\title{
Identification of Fire Hazards Due to Landfill Gas Generation and Emission
}

\author{
Lidija Tihomir Milosevic*, Emina Radomir Mihajlovic, \\ Amelija Vitomir Djordjevic, Milan Zoran Protic, Dejan Petar Ristic
}

University of Niš, Faculty of Occupational Safety in Niš, Čarnojevića 10A, 18000 Niš, Serbia

Received: 27 March 2017

Accepted: 20 June 2017

\begin{abstract}
Since the identification of fire hazards in landfills has not been sufficiently investigated and studied, the goal of this research is to present a methodological approach to the issue. This paper defines fire occurrence indicators, which are considered as one of the risk factors of underground and/or surface fires in non-sanitary landfills. In this study, fire hazards are identified in terms of present landfill gas concentrations and gas well temperatures monitored by a thermal imaging camera at the nonsanitary landfill "Bubanj" in Niš, Serbia, which has been in service for 49 years. Landfill gas concentrations at the landfill were measured from May to October 2015. The paper also presents ambient air temperatures, which influence landfill gas and gas well temperatures, a necessary factor of landfill fires.

Significant fire predictors for the landfill body have been determined based on all the temperatures and concentrations of landfill gas components measured using the statistical method of logistic regression.
\end{abstract}

Keywords: landfill gas, hazard identification, non-sanitary landfill, fire indicators

\section{Introduction}

The last and the only national-level data on waste composition and amount in Serbia dates back to 2010, when the Serbian Government adopted a waste management strategy from 2010 to 2019. With representative samples from 160 municipalities, it was estimated that $0.87 \mathrm{~kg} /$ capita/day of waste was generated in Serbia, which amounted to $318 \mathrm{t} /$ day [1]. By comparison, waste generation in Turkey (Kocaeli) is $0.92 \mathrm{~kg} / \mathrm{capita} / \mathrm{day}$, in Austria (Vienna) $1.50 \mathrm{~kg} / \mathrm{capita} /$ day, and in the USA (New York) it is $2.58 \mathrm{~kg} /$ capita/day [2]. The number of landfill fires in Nišava County, which comprises 71

*e-mail: lidija.milosevic@znrfak.ni.ac.rs settlements and more than 260,000 residents, is highly significant, as indicated by the statistical data of the Sector for Emergency Management, Niš office, for the period between 2009 and 2016, according to which $7.56 \%$ of all open-space fires [3] and $5.60 \%$ of all fires in total were landfill fires. Over the last seven years, out of 7,535 openspace fires, 570 occurred in sanitary, non-sanitary, and illegal landfills. The numbers of landfill fires in Nišava County by year are given in Table 1 .

According to these numbers, it is evident that the number of fires has been declining in recent years as a result of improved landfill fire prevention, implementation, and adherence to laws, analyses of previous fires, learning from previous experience, better citizen cooperation, etc. As opposed to surface fires, which are instantly noticeable, underground landfill fires occur under the 
Table 1. Number of landfill fires in Nišava County, 2009-16.

\begin{tabular}{|c|c|}
\hline Year & Number of landfill fires \\
\hline 2009 & 60 \\
\hline 2010 & 60 \\
\hline 2011 & 106 \\
\hline 2012 & 93 \\
\hline 2013 & 96 \\
\hline 2014 & 37 \\
\hline 2015 & 78 \\
\hline 2016 & 46 \\
\hline
\end{tabular}

surface in deposited waste that is months or even years old [4]. Such fires tend to smoulder for weeks and months non-stop, without any noticeable flame or thick smoke [5]. The fire spreads unnoticed within the landfill body until the surface layer collapses, cracks or depressions appear, or smoke is released. Underground fires usually occur due to an overloaded landfill gas degassing system or due to self-combustion in the landfill body caused by increased temperature due to organic waste decomposition. Cooling, extinguishing, or excavating burning waste is more difficult since it is also difficult to locate hot spots in the waste mass [6].

Based on the occurrence and monitoring of basic fire indicators, it is possible to predict or confirm the presence of an underground fire and locate the hot spots in the landfill body [7]. There are four basic fire indicators:
- Increased temperature in active or passive degassing systems.

- Changed concentrations of landfill gas components.

- Occurrence of cracks, subsidence, or depressions.

- Presence of smoke and odours emanating from the landfill.

\section{Materials and Methods}

\section{Location}

We monitored landfill fire parameters at the Bubanj non-sanitary landfill in Niš. The landfill is located $6 \mathrm{~km}$ from the city centre, in a naturally formed valley, and it has been servicing more than 260,000 people since 1968 . The total area of the landfill is 31.07 ha. It comprises three inactive sections (S1, S2, and S3) and an active section, S4 [8], which covers an area of 2.85 ha (Fig. 1a). S4 has been in use since 2010 and it was designed to be used until 2017. The nearest clustered settlement is more than $1 \mathrm{~km}$ away and the nearest inhabited houses are $200 \mathrm{~m}$ away from the landfill.

The representative amount of municipal waste is $70,000 \mathrm{t} /$ year for the city of Niš, while the total amount of waste deposited in section S4 is $289,538.57 \mathrm{~m}^{3}$ [9]. Table 2 shows the composition of waste in the City of Niš, defined within the project "Determination of the amount and morphological composition of waste in Serbia," which affects landfill gas emissions [9-10]. Since this is a non-sanitary landfill where waste is not sorted, it should be noted that municipal solid waste also

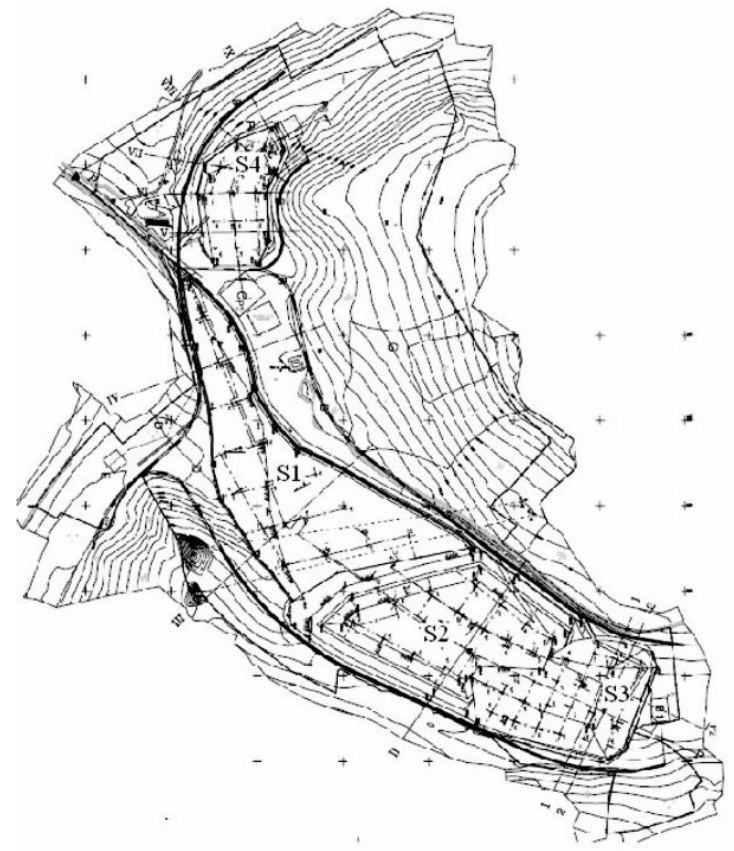

a)

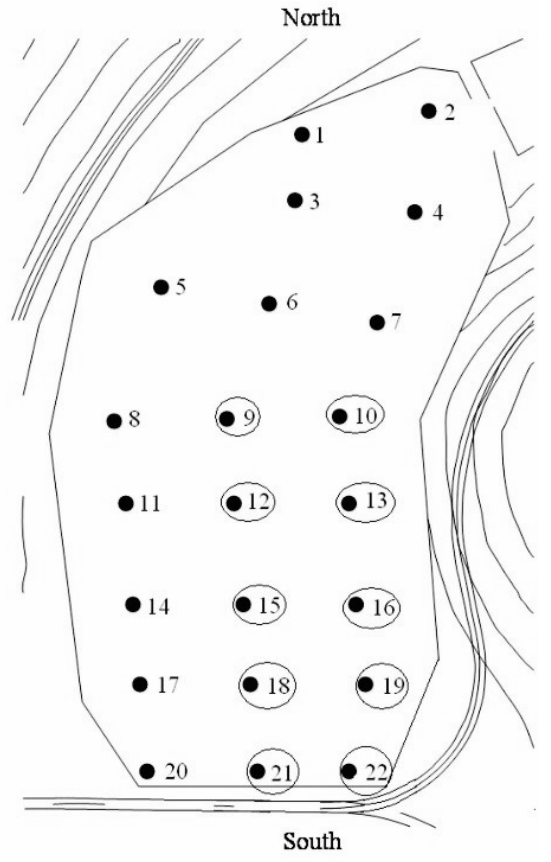

b)

Fig. 1. Bubanj non-sanitary landfill in Niš: a) layout of S1, S2, S3, and S4 landfill sections and b) layout of gas wells in active section $\mathrm{S} 4$ of the landfill. 
Table 2. Morphological composition of municipal waste for the city of Niš.

\begin{tabular}{|c|c|c|}
\hline Waste component & $\begin{array}{c}\text { Mass percentage of } \\
\text { the total amount }(\%)\end{array}$ & $\begin{array}{c}\text { Density } \\
\left(\mathrm{t} / \mathrm{m}^{3}\right)\end{array}$ \\
\hline Garden waste & 10.00 & 0.458 \\
\hline Other biodegradable waste & 30.56 & 0.458 \\
\hline Paper & 7.90 & 0.068 \\
\hline Glass & 4.74 & 0.345 \\
\hline Cardboard & 6.12 & 0.068 \\
\hline Composite materials & 1.33 & 1.000 \\
\hline Packaging waste & 1.38 & 0.679 \\
\hline Aluminium cans & 0.57 & 0.480 \\
\hline Plastic packaging & 3.01 & 0.090 \\
\hline Plastic bags & 9.18 & 0.092 \\
\hline Hard plastics & 5.77 & 0.138 \\
\hline Fabrics & 5.67 & 0.106 \\
\hline Leather & 0.36 & 0.156 \\
\hline Nappies & 4.08 & 0.068 \\
\hline Fine elements & 9.32 & 0.303 \\
\hline
\end{tabular}

contains hazardous and potentially hazardous household waste on which there are no available data [11].

This municipal landfill does not meet the criteria of modern municipal waste management, as waste disposal has not been conducted adequately and in a planned manner, waste has not been properly covered with inert material, its capacities have been exhausted, and environmental protection has not been fully provided. Waste disposal in landfills can also lead to malodours and landfill gas accumulation, possibly leading to fires and explosions, the greenhouse effect, surface and ground water pollution, soil pollution, increased vehicle noise, and health risks for landfill workers [12-13]. The degassing of section S4 was conducted using a passive landfill gas degassing system by placing 22 24-m-long gas wells $25 \mathrm{~m}$ from one another.

\section{Measurement Period}

Since the highest incidence of landfill fires is between March and August, when c. $60 \%$ of all annual landfill fires occur, we monitored the parameters from May to October during the morning hours [5, 14]. According to the data from the Hydrometeorological Service of Serbia for Niš, the summer months of June, July, and August have mean maximum average temperatures of $27.1^{\circ} \mathrm{C}$, $29.8^{\circ} \mathrm{C}$, and $30.1^{\circ} \mathrm{C}$, respectively [15]. July and August have the lowest mean monthly relative air humidity (61\%) as well as the primary minimum of precipitation. The analysis of average annual wind frequency indicates that northwesterly winds are prevalent, followed by northeasterly winds.

\section{Methodology}

We performed measurements of landfill gas temperature and component concentrations using the German MRU Vario Plus Industrial $\mathrm{GmbH}$ according to standards SRPS ISO 10780:2010, EPA 3A:2008, EPA 10:2006, EPA 7E:2008, EPA 6C:2008, EPA CTM 030, and EPA CTM 034 [16-22]. Gas well temperatures were measured using an EasIR-9 thermal imaging camera [23].

Considering that the Bubanj landfill contains a passive degassing system, measurements were conducted on 10 accessible gas wells (Fig. 1b).

Univariate and multivariate logistic regression analyses were used to identify landfill fire predictors. Based on significant characteristics of interest for landfill fire possibility obtained from the univariate logistics regression (enter method), a multivariate linear regression (backward conditional method) was carried out.

\section{Results and Discussion}

The results of six-month measurements of temperature and landfill gas component concentrations at Bubanj are shown in Table 3.

\section{Temperature Monitoring}

Monitoring landfill gas and gas well temperatures as a reliable fire indicator has proven useful both for landfill fire prevention and for establishing fire risk and monitoring the course of suppression. Landfill temperature depends on landfill size and capacity, climate conditions, and organization of waste disposal [24]. Gas well temperature was measured using a thermal imaging camera. Fig. 2 shows gas well temperature measurements for July 2015.

Fig. 3 shows the six-month measurements of gas well temperature using a thermal imaging camera, indicating that the temperature ranged from $24.9^{\circ} \mathrm{C}$ (well No. 9) to $48.9^{\circ} \mathrm{C}$ (well No. 18). The imaging did not reveal any temperature increase above $65^{\circ} \mathrm{C}$, so there is no possibility of a landfill fire at the Niš landfill [25].

Since the landfill temperature in its aerobic phase, which lasts from several days to several weeks, ranges from 80 to $90^{\circ} \mathrm{C}$, and in the subsequent anaerobic phase, which lasts for years, the temperature ranges from 30 to $50^{\circ} \mathrm{C}$, any increase in temperature indicates the presence of hot spots [26]. Fig. 4 shows the measured landfill gas temperatures.

The measured temperatures shown in Fig. 4 range from $25.2^{\circ} \mathrm{C}$ (No. 9) to $51^{\circ} \mathrm{C}$ (No. 18). Regular landfill body temperature is up to $52^{\circ} \mathrm{C}$, while temperatures over $55^{\circ} \mathrm{C}$ indicate heating, temperatures between $100^{\circ} \mathrm{C}$ and $121^{\circ} \mathrm{C}$ indicate subsurface smouldering, and temperatures over $149^{\circ} \mathrm{C}$ are certain sign of a fire [27-29]. Based on the measured values, we concluded that this indicator does 
Table 3. Results of landfill gas temperature and concentration component measurements.

\begin{tabular}{|c|c|c|c|c|c|c|c|c|}
\hline \multirow[b]{2}{*}{ Date } & \multirow{2}{*}{$\begin{array}{l}\text { Ambient temperature } \\
\left({ }^{\circ} \mathrm{C}\right)\end{array}$} & \multirow{2}{*}{$\begin{array}{l}\text { Gas } \\
\text { well }\end{array}$} & \multirow{2}{*}{$\begin{array}{c}\text { Gas well } \\
\text { temperature }\left({ }^{\circ} \mathrm{C}\right)\end{array}$} & \multirow{2}{*}{$\begin{array}{c}\text { Landfill gas } \\
\text { temperature }\left({ }^{\circ} \mathrm{C}\right)\end{array}$} & \multicolumn{4}{|c|}{ Concentration } \\
\hline & & & & & $\begin{array}{c}\mathrm{CH}_{4} \\
(\% \mathrm{vol})\end{array}$ & $\begin{array}{c}\mathrm{CO}_{2} \\
(\% \mathrm{vol})\end{array}$ & $\begin{array}{c}\mathrm{O}_{2} \\
(\% \text { vol })\end{array}$ & $\begin{array}{c}\mathrm{CO} \\
(\mathrm{ppm})\end{array}$ \\
\hline \multirow{10}{*}{$\begin{array}{l}7 \text { May } \\
2015\end{array}$} & \multirow{10}{*}{31} & 9 & 29.3 & 28.5 & 6.90 & 14.2 & 19.3 & 2 \\
\hline & & 10 & 30.8 & 29.6 & 5.90 & 14.8 & 19.1 & 2 \\
\hline & & 12 & 28.9 & 27.3 & 4.60 & 13.9 & 20.8 & 2 \\
\hline & & 13 & 34.8 & 32.6 & 8.10 & 15.5 & 20.3 & 1 \\
\hline & & 15 & 35.9 & 35.0 & 4.90 & 13.1 & 18.2 & 2 \\
\hline & & 16 & 36.7 & 35.7 & 0.70 & 15.7 & 19.4 & 2 \\
\hline & & 18 & 37.0 & 39.1 & 0.70 & 14.2 & 19.8 & 2 \\
\hline & & 19 & 33.9 & 34.8 & 0.80 & 14.9 & 20.1 & 1 \\
\hline & & 21 & 30.2 & 32.0 & 20.10 & 13.4 & 20.4 & 1 \\
\hline & & 22 & 32.2 & 33.6 & 19.70 & 14.6 & 18.9 & 2 \\
\hline \multirow{10}{*}{$\begin{array}{l}4 \text { June } \\
2015\end{array}$} & \multirow{10}{*}{29} & 9 & 28.5 & 29.0 & 6.40 & 13.6 & 20.5 & 1 \\
\hline & & 10 & 31.2 & 30.6 & 5.80 & 14.5 & 19.7 & 1 \\
\hline & & 12 & 29.1 & 28.9 & 4.50 & 13.8 & 20.1 & 2 \\
\hline & & 13 & 37.4 & 39.4 & 7.90 & 14.9 & 20.4 & 1 \\
\hline & & 15 & 37.3 & 39.5 & 4.70 & 12.9 & 19.3 & 2 \\
\hline & & 16 & 36.9 & 38.2 & 0.60 & 15.7 & 18.9 & 1 \\
\hline & & 18 & 40.0 & 42.7 & 0.65 & 14.2 & 20.3 & 2 \\
\hline & & 19 & 36.2 & 36.4 & 0.70 & 14.6 & 20.5 & 1 \\
\hline & & 21 & 33.7 & 32.1 & 19.50 & 13.0 & 18.8 & 1 \\
\hline & & 22 & 34.9 & 34.3 & 18.50 & 13.8 & 17.0 & 2 \\
\hline \multirow{10}{*}{$\begin{array}{l}2 \text { July } \\
2015\end{array}$} & \multirow{10}{*}{27} & 9 & 29.9 & 29.6 & 6.30 & 2.0 & 20.2 & 0 \\
\hline & & 10 & 32.8 & 31.3 & 5.80 & 3.4 & 20.3 & 0 \\
\hline & & 12 & 29.9 & 30.5 & 4.40 & 3.9 & 20.5 & 0 \\
\hline & & 13 & 30.1 & 31.1 & 7.80 & 3.0 & 20.6 & 0 \\
\hline & & 15 & 39.4 & 43.4 & 4.60 & 5.0 & 18.6 & 1 \\
\hline & & 16 & 35.5 & 39.6 & 0.77 & 1.8 & 19.8 & 0 \\
\hline & & 18 & 48.9 & 51.0 & 0.28 & 0.1 & 20.68 & 2 \\
\hline & & 19 & 35.5 & 37.4 & 0.53 & 1.5 & 20.1 & 0 \\
\hline & & 21 & 32.9 & 32.9 & 19.40 & 12.9 & 19.5 & 0 \\
\hline & & 22 & 35.0 & 35.8 & 18.50 & 12.0 & 15.0 & 1 \\
\hline \multirow{10}{*}{$\begin{array}{l}12 \mathrm{Aug} \\
2015\end{array}$} & \multirow{10}{*}{36} & 9 & 30.9 & 32.1 & 8.20 & 6.7 & 19.3 & 0 \\
\hline & & 10 & 32.8 & 33.4 & 5.40 & 4.6 & 20.6 & 1 \\
\hline & & 12 & 35.9 & 35.5 & 6.40 & 5.9 & 19.3 & 1 \\
\hline & & 13 & 34.1 & 36.3 & 6.10 & 2.1 & 18.1 & 0 \\
\hline & & 15 & 40.4 & 47.1 & 5.20 & 3.3 & 19.4 & 1 \\
\hline & & 16 & 37.2 & 38.6 & 2.80 & 4.9 & 19.2 & 1 \\
\hline & & 18 & 42.0 & 47.5 & 3.40 & 2.4 & 19.6 & 1 \\
\hline & & 19 & 36.7 & 39.4 & 4.70 & 3.4 & 20.5 & 0 \\
\hline & & 21 & 34.9 & 35.3 & 22.50 & 15.6 & 19.8 & 1 \\
\hline & & 22 & 35.2 & 36.5 & 21.30 & 18.3 & 18.4 & 0 \\
\hline
\end{tabular}


Table 3. Continued.

\begin{tabular}{|c|c|c|c|c|c|c|c|c|}
\hline \multirow{10}{*}{$\begin{array}{c}16 \text { Sep } \\
2015\end{array}$} & \multirow{10}{*}{33} & 9 & 29.5 & 30.8 & 7.20 & 8.1 & 20.7 & 1 \\
\hline & & 10 & 30.6 & 32.4 & 7.60 & 5.3 & 20.4 & 1 \\
\hline & & 12 & 30.2 & 31.4 & 8.10 & 6.8 & 21.2 & 0 \\
\hline & & 13 & 32.6 & 33.5 & 9.40 & 7.7 & 19.5 & 1 \\
\hline & & 15 & 38.7 & 44.7 & 4.00 & 2.4 & 19.3 & 0 \\
\hline & & 16 & 37.5 & 40.6 & 3.50 & 5.4 & 20.0 & 0 \\
\hline & & 18 & 39.9 & 48.2 & 4.10 & 3.2 & 19.3 & 1 \\
\hline & & 19 & 36.3 & 38.1 & 6.80 & 4.6 & 19.8 & 0 \\
\hline & & 21 & 33.3 & 35.5 & 19.70 & 16.7 & 20.8 & 2 \\
\hline & & 22 & 35.7 & 36.2 & 20.30 & 15.5 & 19.2 & 1 \\
\hline \multirow{10}{*}{$\begin{array}{c}19 \text { Oct } \\
2015\end{array}$} & \multirow{10}{*}{24} & 9 & 24.9 & 25.2 & 5.50 & 3.2 & 19.3 & 2 \\
\hline & & 10 & 25.8 & 28.4 & 6.40 & 7.4 & 20.7 & 0 \\
\hline & & 12 & 25.7 & 29.8 & 7.10 & 4.7 & 20.3 & 1 \\
\hline & & 13 & 26.5 & 29.7 & 5.30 & 3.1 & 20.6 & 1 \\
\hline & & 15 & 27.0 & 35.6 & 2.10 & 3.8 & 19.7 & 0 \\
\hline & & 16 & 28.7 & 34.6 & 3.80 & 1.9 & 20.8 & 0 \\
\hline & & 18 & 26.7 & 33.8 & 1.30 & 2.7 & 19.2 & 1 \\
\hline & & 19 & 29.9 & 39.8 & 7.40 & 6.4 & 19.8 & 1 \\
\hline & & 21 & 27.0 & 30.4 & 15.30 & 12.5 & 20.2 & 1 \\
\hline & & 22 & 26.9 & 28.4 & 16.70 & 14.2 & 20.7 & 0 \\
\hline
\end{tabular}

not suggest a possibility of fire occurrence or confirm the presence of an underground fire.

\section{Monitoring Carbon Monoxide Concentrations}

A change in $\mathrm{CO}$ concentration can be used as a reliable indicator of underground fires. Due to non-homogeneity of deposited waste and depending on landfill maintenance, $\mathrm{CO}$ concentration reduction may take from one to six months. Table 4 provides the $\mathrm{CO}$ concentrations taken as the qualitative factor of the probability of fire occurrence in the landfill body [4].

Fig. 5 shows measured $\mathrm{CO}$ values in gas wells. The lowest measured CO concentration was $0.0001 \%_{\text {vol }}$, while the highest was $0.0002 \%_{\mathrm{vol}}$ - both of which are lower than the maximum allowed concentration of $0.0025 \%$ vol.

$\mathrm{CO}$ concentrations in other gas wells were not registered. All of this reveals that this indicator does not suggest a possibility of fire occurrence or confirm the presence of an underground fire.

\section{Monitoring Oxygen Concentrations}

According to the US EPA and SWANA, regular oxygen concentrations range from $0.1 \%_{\text {vol }}$ to $1 \%_{\text {vol }}$, while the maximum allowed concentration is up to $5 \%_{\mathrm{vol}}$. During a landfill fire, the level of subsurface oxygen ranges from $15 \%_{\text {vol }}$ to $21 \%_{\text {vol }}$ [27-29]. As fire suppression progresses, the oxygen level drops proportionally, and when the fire has been extinguished, the oxygen level usually drops below $1 \%{ }_{\text {vol }}$. Fig. 6 shows the measured oxygen concentrations.
The measured oxygen concentrations in gas wells ranged from $15 \%_{\text {vol }}$ (well No. 22) to $21.2 \%_{\text {vol }}$ (No. 12). Increased oxygen concentrations in gas wells suggest a possibility of fire occurrence, but since both the temperature and $\mathrm{CO}$ concentrations were within their regular range, the increase in oxygen was caused by air penetrating the landfill body due to an insufficient amount of cover layer and the inadequately designed and installed passive degassing system [30].

\section{Monitoring Methane Concentrations}

Methane formation begins in the fourth, or anaerobic, phase of waste decomposition, when the ratio of $\mathrm{CO}_{2}$ and methane is approximately $1: 1$, and together they constitute about $95 \%$ of the total amount of landfill gas. Methane and $\mathrm{CO}_{2}$ concentrations, whose regular range is c. $45 \%$ to $60 \%_{\text {vol }}$, decrease during underground fires [26]. Only 50 to $90 \%$ of landfill gas can be emitted through landfill collection systems [31]. Fig. 7 shows the measured values of methane concentrations in gas wells.

In addition to contributing to the greenhouse effect, methane is also a flammable, explosive, and toxic gas [32]. Since the flammable/explosive limits of methane range from $5 \%_{\text {vol }}$ to $15 \%_{\text {vol }}$, the measured values reveal that methane was constantly within its explosive range over the six months in gas well Nos. 9, 10, and 13. There were a total of 24 gas wells that were within their explosive range. The highest measured concentration of methane was $22.5 \%_{\mathrm{vol}}$ in well No. 21 in August, while the lowest measured concentration was 

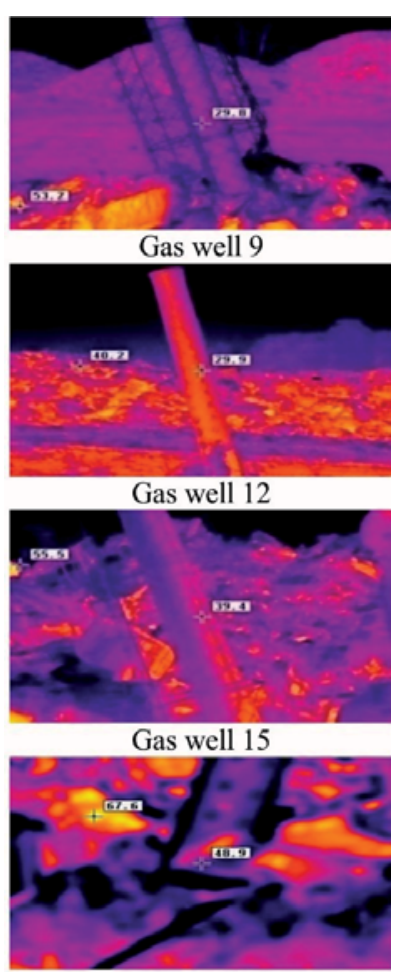

Gas well 18

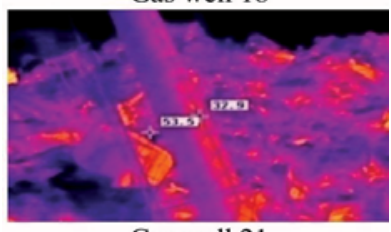

Gas well 21

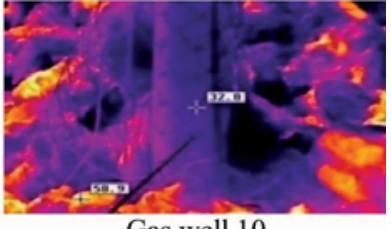

Gas well 10

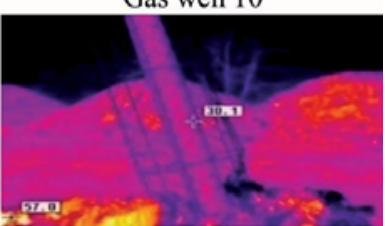

Gas well 13

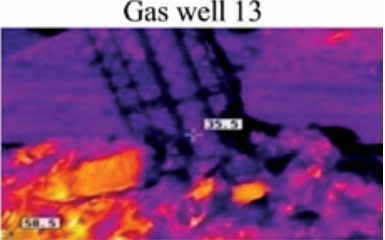

Gas well 16

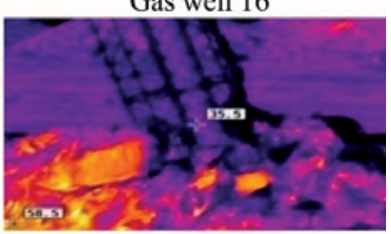

Gas well 19

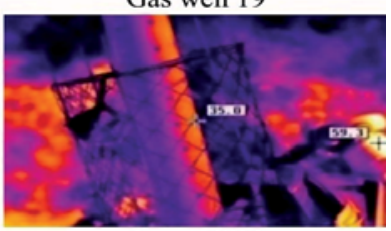

Gas well 22

Fig. 2. Thermal images of gas wells.

$0.28 \%_{\text {vol }}$ in well No. 18 in July, which was the result of daily and seasonal concentration variations [33].

\section{Monitoring Carbon Dioxide Concentrations}

The measured $\mathrm{CO}_{2}$ concentrations shown in Table 3 ranged from $0.1 \%_{\text {vol }}$ in well No. 18 to $16.7 \%_{\text {vol }}$ in No. 21 . The ratio of methane and $\mathrm{CO}_{2}$ with a value lower than 1 is an indicator of probability of underground landfill fire occurrence, and it was registered in 24 gas

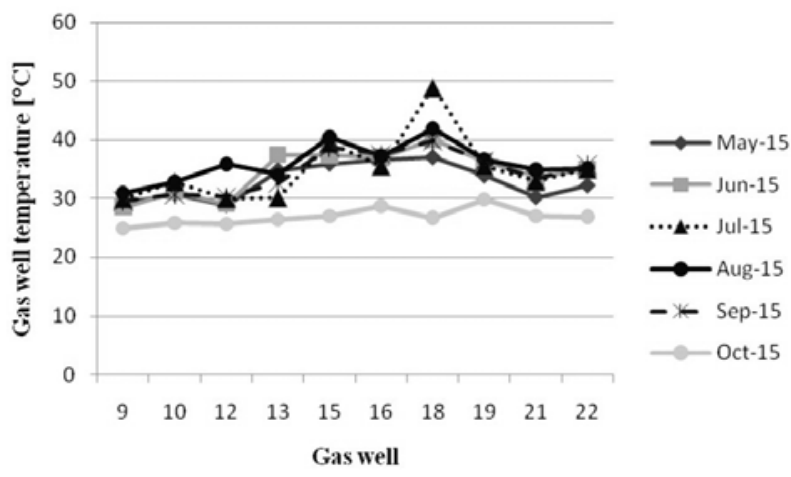

Fig. 3. Gas well temperatures.

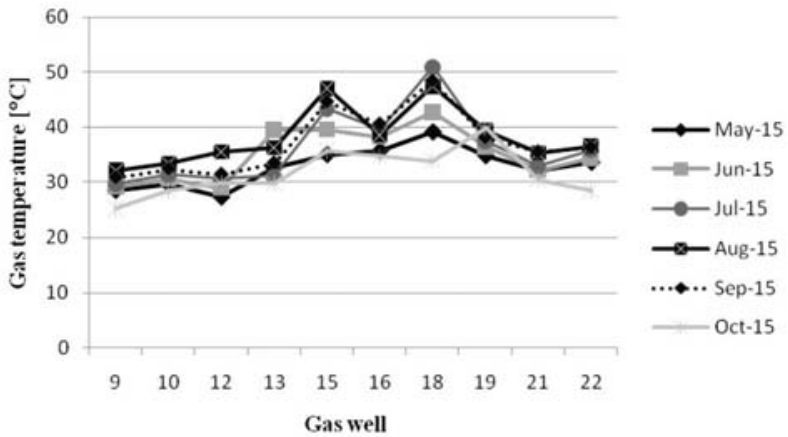

Fig. 4. Landfill gas temperatures in gas wells.

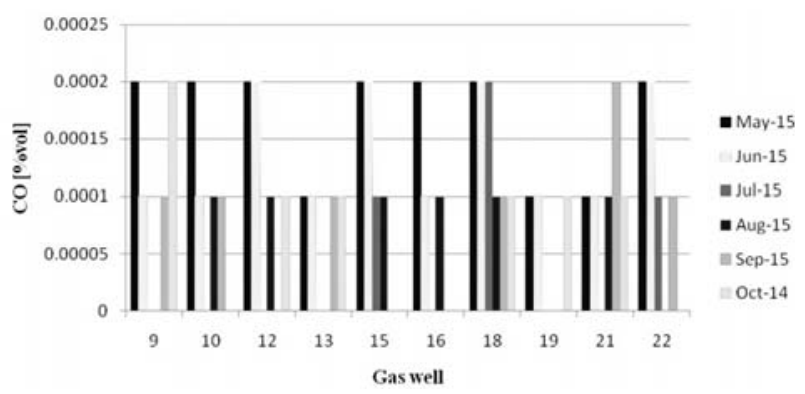

Fig. 5. CO concentrations in gas wells.

wells [29]. In May and June, the risk of fire was observed in gas well Nos. 9, 10, 12, 13, 15, 16, 18, and 19.

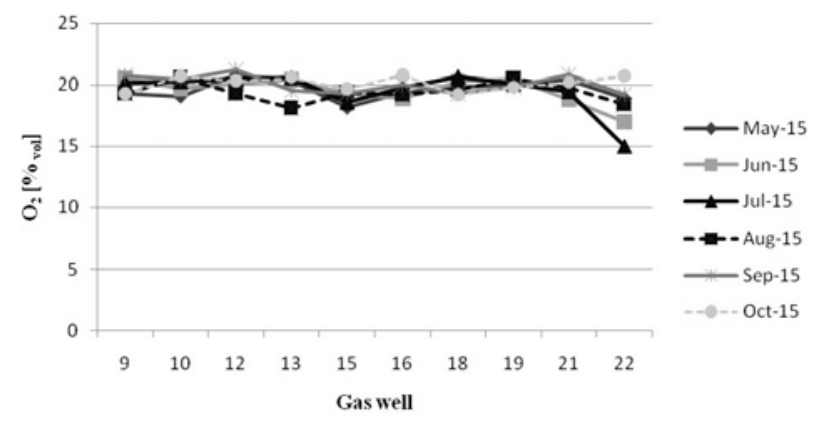

Fig. 6. Oxygen concentrations in gas wells.

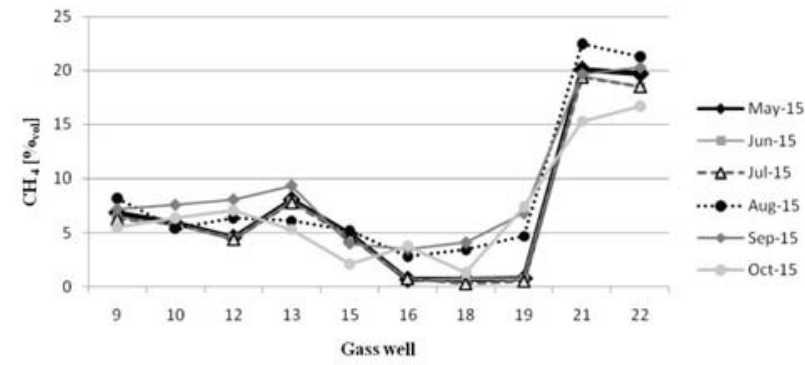

Fig. 7. Methane concentrations in gas wells. 
Table 4. Empirical scale for assessing fire occurrence in a landfill body based on $\mathrm{CO}$ concentration.

\begin{tabular}{|c|c|}
\hline $\begin{array}{c}\text { CO concentration } \\
\left(\%_{\text {vol }}\right)\end{array}$ & $\begin{array}{c}\text { Possibility of fire in the } \\
\text { landfill body }\end{array}$ \\
\hline $0-0.0025$ & No fire \\
\hline $0.0025-0.01$ & Possible fire in the landfill body \\
\hline $0.01-0.05$ & Possible smouldering fire \\
\hline $0.05-0.1$ & Probable fire in the landfill body \\
\hline$>0.1$ & Fire in the landfill body \\
\hline
\end{tabular}

\section{Occurrence of Cracks, Depressions, Smoke,} and Malodours

We did not observe any cracks, subsidence, or depressions - indicators of certain underground fire occurrences - on the Bubanj landfill surface. Likewise, we observed no smoke or odours emanating from either the landfill surface or the gas wells.

\section{Statistical Analysis of Fire Indicators}

Since no fires broke out at the landfill during the observed period, due to the absence of cases where the values of two key fire factors were higher than the reference values (landfill gas temperature $>55^{\circ} \mathrm{C}$ or carbon monoxide concentration $\geq 0.0025 \%$ vol ), the probability of fire outbreak as a dependent variable can be determined based on other examined parameters in which the values fall within the outbreak range.

On the other hand, $\mathrm{O}_{2}$ concentrations over the entire observed period were double the reference fire values $\left(>5 \%_{\mathrm{vol}}\right)$. If the simultaneous presence of methane concentration with the flammable range from $5 \%_{\mathrm{vol}}$ to $15 \%$ vol and the ratio of methane and $\mathrm{CO}_{2}$ concentrations $<1$ are taken as the dependent variable, i.e., a possible fire,

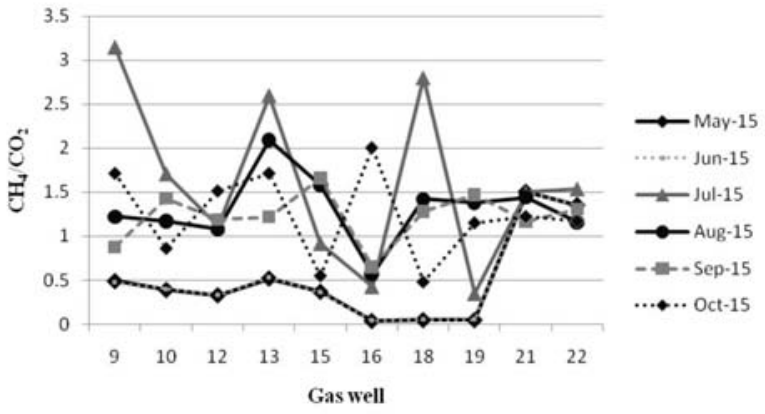

Fig. 8. Ratio of methane and $\mathrm{CO}_{2}$ concentrations.

according to the experimental data, the probability of a fire outbreak in the landfill body is $15 \%$ (in nine out of 60 gas wells). The statistical method of logistical regression was used to determine landfill body fire predictors, and the results are shown in Table 5.

The univariate logistical analysis of independent variables, defined by their continuous values or as categorical, dichotomous variables (in relation to landfill fire reference values), has shown that $\mathrm{CO}_{2}$ concentration and the ratio of methane and $\mathrm{CO}_{2}$ concentrations are the only statistically significant variables. $\mathrm{CO}_{2}$ concentration increases by one unit of measurement lead to an increase in the ratio of fire outbreak probabilities by 0.209 (IP: 1.018-1.437; $\mathrm{p}<0.05) . \mathrm{CO}_{2}$ concentration change causes $17.21 \%$ of the changes of fire probability ratios. An increase in the ratio of methane and $\mathrm{CO}_{2}$ concentrations by one unit of measurement decreases the fire probability ratio by 0.836 (IP: $0.036-0.742 ; \mathrm{p}<0.05$ ). Change of the ratio of methane and $\mathrm{CO}_{2}$ concentrations causes $20.58 \%$ of the changes of fire probability ratios.

In order to determine the synergistic effect of the variables designated as statistically significant by univariate logistical regression, they were included in the model of multivariate logistical regression. The backward

Table 5. Results of univariate logistical regression analyses for a possible fire outbreak at Bubanj non-sanitary landfill in Niš, Serbia, from May to October 2015.

\begin{tabular}{|c|c|c|c|c|c|}
\hline \multirow[t]{2}{*}{ Fire indicators } & \multirow{2}{*}{$\begin{array}{c}\text { Nagelkerke R Square } \\
\mathrm{R}^{2}\end{array}$} & \multirow{2}{*}{$\begin{array}{l}\text { Odd Ratio } \\
\text { OR }\end{array}$} & \multicolumn{2}{|c|}{$\begin{array}{c}\text { Confidence interval } \\
95.0 \% \mathrm{CI}\end{array}$} & \multirow{2}{*}{$\begin{array}{l}\text { Statistical } \\
\text { significance } \\
\text { (p value) }\end{array}$} \\
\hline & & & Lower & Upper & \\
\hline Ambient temperature & 0.0039 & 0.966 & 0.806 & 1.159 & 0.7123 \\
\hline Gas well temperature & 0.0424 & 0.904 & 0.764 & 1.071 & 0.2431 \\
\hline Landfill gas temperature & 0.1188 & 0.844 & 0.702 & 1.015 & 0.0720 \\
\hline $\mathrm{O}_{2}$ concentration & 0.0302 & 1.567 & 0.608 & 4.040 & 0.3524 \\
\hline $\mathrm{CO}_{2}$ concentration & 0.1721 & 1.209 & 1.018 & 1.437 & 0.0307 \\
\hline $\mathrm{CH}_{4}$ concentration & 0.0088 & 0.967 & 0.855 & 1.094 & 0.5946 \\
\hline $\mathrm{CH}_{4}$ concentration $5-15 \%_{\mathrm{vol}}$ & 0.4554 & $908,704,568.155$ & 0.000 & - & 0.9976 \\
\hline $\mathrm{CH}_{4} / \mathrm{CO}_{2}$ concentration & 0.2058 & 0.164 & 0.036 & 0.742 & 0.0189 \\
\hline $\mathrm{CH}_{4} / \mathrm{CO}_{2}$ concentration $<1$ & 0.4554 & $908,704,568.155$ & 0.000 & - & 0.9976 \\
\hline
\end{tabular}


conditional method determined that the only statistically significant variable with the same significance is the ratio of methane and $\mathrm{CO}_{2}$ concentrations.

\section{Conclusions}

Based on measurements aimed at identifying fire hazards, we monitored fire indicators at the Bubanj nonsanitary landfill in Niš, Serbia, from May to October 2015. Gas well temperatures ranged from $24.9^{\circ} \mathrm{C}$ to $48.9^{\circ} \mathrm{C}$ and landfill gas temperatures from $25.2^{\circ} \mathrm{C}$ to $51^{\circ} \mathrm{C}$, while carbon monoxide concentrations did not exceed $0.0002 \%_{\text {vol }}$, which falls within the normal range of values and does not indicate a combustion process. The absence of indicators such as smoke, odours, cracks, or depressions in the landfill body only confirmed that there was no underground fire or likelihood of one.

The measured oxygen concentrations in gas wells ranged from $15 \%_{\text {vol }}$ to $21.2 \%_{\text {vol }}$, which indicates that normal values were exceeded in each of the 10 measured gas wells during the six-month period. The measured methane concentrations indicated that fire risk is the highest in August in gas well Nos. 9, 10, 12, 13, and 15, and in September in gas well Nos. 9, 10, 12, 13, and 19. Another fire indicator, ratio of methane and carbon dioxide, revealed that the probability of a fire was particularly high in May and June in gas well Nos. 9, 10, $12,13,15,16,18$, and 19 .

A comprehensive analysis of all fire indicators at Bubanj from May to October 2015 showed that fire risk was particularly high in May and June in gas well Nos. 9, 10, and 13 .

Upon determining the synergistic effect of fire indicators using univariate logistical regression, carbon dioxide concentration and the ratio of methane and carbon dioxide concentrations were found to be statistically significant fire indicators.

There is a $15 \%$ probability of fire in the landfill body due to the simultaneous presence of methane concentrations within its flammable range and the ratio of methane and $\mathrm{CO}_{2}$ concentrations of less than one. $\mathrm{CO}_{2}$ concentration change causes $17.21 \%$, whereas the change of the ratio of methane and $\mathrm{CO}_{2}$ concentrations causes $20.58 \%$ of the changes of fire probability ratios.

\section{References}

1. Waste Management Strategy from 2010 to 2019, "Official Gazette of the Republic of Serbia" No. 29/2010. [In Serbian] http://www.eko.minpolj.gov.rs/dokumenti/ (accessed on 11.02.2016).

2. ÖZBAY İ. Evaluation of municipal solid waste management practices for an industrialized city. Pol. J. Environ. Stud. 24 (2), 637, 2015.

3. MILOSEVIC L. Methodological approach to landfill fire risk assessment for the purpose of air pollution evaluation. Doctoral dissertation. University of Nis. Faculty of Occupational Safety in Nis. 2016 [In Serbian].
4. RADOSAVLJEVIC J., DJORDJEVIC A. Municipal waste landfills and disposal. University of Nis, Faculty of Occupational Safety in Nis, 2013. [In Serbian].

5. Federal Emergency Management Agency. Landfill fires their magnitude, characteristic, and mitigation. United States Fire Administration. National Fire Data Center. 2002 http:// www.sustainable-design.ie/fire/FEMA-LandfillFires.pdf (accessed on 09.04.2016)

6. MIHAJLOVIC E., MLADJAN D., JANKOVIC Z. Firefighting Procedures and Agents, University of Nis, Faculty of Occupational Safety in Nis, 2009 [In Serbian].

7. Review and Investigation of deep-seated fires within landfill sites, Science Report: SC010066, Environment Agency. 2007. https://www.gov.uk/government/uploads/ system/uploads/attachment_data/file/365144/review_and_ investigation_of_deep-seated_fires_within_landfill_sites. pdf (accessed on 17.03.2016)

8. Main project of recovery, closure, and recultivation of "Bubanj" landfill in Niš, Project for landfill gas reception and venting 1218/1.G.00.MP, Institute "Kirilo Savić" JSC, Belgrade, 2005 [In Serbian].

9. Main project of recovery, closure, and recultivation of the S4 section of "Bubanj" landfill in Niš, Hidrozavod DTD JSC Novi Sad, 2014 [In Serbian].

10. DONOVAN S.M., PAN J., BATESON T., GRONOW J.R., VOULVOULIS N. Gas emissions from biodegradable waste in United Kingdom landfills. Waste Management \& Research. 29 (1), 69, 2011.

11. ADAMCOVÁ D, VAVERKOVÁ M.D., STEJSKAL B., BŘOUŠKOVÁ E. Household solid waste composition focusing on hazardous waste. Pol. J. Environ. Stud. 25 (2), 487, 2016.

12. GHANBARI F., SHAREE A.F., MONAVARI M., ZAREDAR N. A new method for environmental site assessment of urban solid waste landfills. Environ Monit Assess. 184 (3), 1221, 2012.

13. SHARMA A., MEESA S., PANT S., ALAPPAT B. J., KUMAR D. Formulation of a landfill pollution potential index to compare pollution potential of uncontrolled landfills. Waste Management \& Research. 26 (5), 474, 2008.

14. IBRAHIM M.A., GÖRANSSON G., KACZALA F., HOGLAND W., MARQUES M. Characterization of municipal solid waste temporary storage sites: Risks posed to surrounding areas as a consequence of fire incidents. Waste Management. 33 (11), 2296, 2013.

15. Republic Hydrometeorological Service of Serbia, http:// www.hidmet.gov.rs (accessed on 20.11.2016)

16. SRPS ISO 10780:2010 Stationary source emissions Measurement of velocity and volume flow rate of gas flows in ducts. Institute for Standardization of Serbia. Belgrade 2010. [In Serbian] http://www.iss.rs/standard/?natstandard document_id=24097 (accessed on 03.05.2016)

17. Method 3A - Determination of oxygen and carbon dioxide concentrations in emissions from stationary sources (Instrumental analyzer procedure). http://www3.epa.gov/ ttn/emc/promgate/method3A.pdf (accessed on 15.07.2016)

18. Method 10 - Determination of carbon monoxide emissions from stationary sources (Instrumental analyzer procedure). http://www3.epa.gov/ttn/emc/promgate/method10r06.pdf (accessed on 20.05.2016)

19. Method 7E - Determination of nitrogen oxides emissions from stationary sources (Instrumental analyzer procedure). http://www3.epa.gov/ttn/emc/promgate/method7E.pdf (Accessed on 20.07.2016)

20. Method 6C - Determination of sulfur dioxide emissions from stationary sources (Instrumental analyzer procedure). 
http://www3.epa.gov/ttn/emc/promgate/method6C.pdf (accessed on 23.06.2016)

21. Method 6C - Determination of sulfur dioxide emissions from stationary sources (Instrumental analyzer procedure). http://www3.epa.gov/ttn/emc/promgate/method6C.pdf (accessed on 23.06.2016)

22. Determination of nitrogen oxides, carbon monoxide, and oxygen emissions from natural gas-fired engines, boilers and process heaters using portable analyzers. http://www3. epa.gov/ttn/emc/ctm/ctm-030.pdf (accessed on 12.12.2016)

23. Test Method - Determination of oxygen, carbon monoxide and oxides of nitrogen from stationary sources for periodic monitoring (Portable electrochemical analyzer procedure). http://www3.epa.gov/ttn/emc/ctm/ctm-034.pdf (Accessed on 23.11.2016)

24. Guide EasIR-9 Infrared thermal imaging camera http:// www.amazon.com/Guide-EasIR-9-Electrical-inspectiondiagnostics/dp/B00Q6F0648 (Accessed on 10.05.2015)

25. VAVERKOVÁ M., ADAMCOVÁ D. Long-term temperature monitoring of a municipal solid waste landfill. Pol. J. Environ. Stud. 24 (3), 1373, 2015.

26. JAFARI N.H., STARK T.D., THALHAMER T. Spatial and temporal characteristics of elevated temperatures in municipal soil waste landfills. Waste Management. 59, 286, 2017.

27. WILLIAMS, P.T. Waste treatment and disposal. Second edition, John Wiley \& Sons, 2005.

28. U.S. Environmental Protection Agency (US EPA), Guidance for evaluating landfill gas emissions from closed or abandoned facilities, 2005. https://cfpub.epa.gov/si/si public_record_report.cfm?dirEntryId $=137824$ (accessed on 17.11.2016)

29. Solid Waste Association of North America (SWANA), Landfill gas operation and maintenance, manual of practice, 1997 http://www.nrel.gov/docs/legosti/fy97/23070.pdf (accessed on 31.12.2016)

30. Hammer Consulting Services, Providing environmental response and engineering for waste fires and disasters. Missouri. September 1. 2015. https://dnr.mo.gov/env/ swmp/facilities/docs/agobridgeeva192015.pdf (accessed on 5.02.2017)

31. CHIEMCHAISRI C., CHIEMCHAISRI W., KUMAR S., HETTIARATCHI J. P. A. Solid waste characteristics and their relationship to gas production in tropical landfill. Environ Monit Assess. 135 (1-3), 41, 2007.

32. GONZALEZ-VALENCIA R., MAGANA-RODRIGUEZ F., MALDONADO E., SALINAS J., THALASSO F. Detection of hotspots and rapid determination of methane emissions from landfills via a ground-surface method. Environ Monit Assess. 187 (1), 4083, 2015.

33. NWACHUKWU A. N., ANONYE D. The effect of atmospheric pressure on $\mathrm{CH}_{4}$ and $\mathrm{CO}_{2}$ emission from a closed landfill site in Manchester, UK. Environ Monit Assess. 185 (7), 5729, 2013.

34. SÁNCHEZ M. L., GARCÍA M. Á., PÉREZ I. A., PARDO $\mathrm{N}$. $\mathrm{CH}_{4}$ continuous measurements in the upper Spanish plateau. Environ Monit Assess. 186 (5), 2823, 2014. 